\title{
A new record of the brassy chub, Kyphosus vaigiensis (Actinopterygii: Perciformes: Kyphosidae), from the Mediterranean Sea
}

\author{
Lilia Labiba GROUD ${ }^{1}$, Lamya CHAOUI ${ }^{1}$, M. Hichem KARA ${ }^{1}$ \\ 1 Laboratoire Bioressources Marines, Université d'Annaba Badji Mokhtar, Annaba, Algeria \\ http://zoobank.org/FF5F15F1-2CC6-461F-8A39-27A0733EFC76
}

Corresponding author: M. Hichem Kara (kara_hichem@yahoo.com)

Academic editor: P. Karachle • Received 14 July 2020 • Accepted 6 February 2021 • Published 12 July 2021

Citation: Groud LL, Chaoui L, Kara MH (2021) A new record of the brassy chub, Kyphosus vaigiensis (Actinopterygii: Perciformes: Kyphosidae), from the Mediterranean Sea. Acta Ichthyologica et Piscatoria 51(2): 219-223. https://doi.org/10.3897/aiep.51.64069

\section{Abstract}

One individual of the brassy chub, Kyphosus vaigiensis (Quoy et Gaimard, 1825) (41.5 cm TL, $1.27 \mathrm{~kg} \mathrm{TW}$ ), was caught off Annaba, on the eastern coasts of Algeria in December 2013. This circumtropical fish is found for the first time on the south-western Mediterranean coasts. The chronology of its records in the Mediterranean supports the hypothesis of its Atlantic origin.

\section{Keywords}

alien species, first record, Kyphosus vaigiensis, Mediterranean, Algeria

\section{Introduction}

The taxonomy of sea chubs (Kyphosidae, Kyphosus) was confused for a long time (Orsi Relini 2017). The perciform family Kyphosidae currently accommodates 12 species in two genera: Neoscorpis Smith, 1931 and Kyphosus Lacepède, 1801 (see Knudsen and Clements 2013, 2016; Knudsen et al. 2019). Their morphology is uniform with only subtle variations among species (Humann 1994). The genus Kyphosus is represented by 11 species widely distributed in the Atlantic, Indian, and the Pacific oceans (Sakai and Nakabo 1995, 2014, 2016; Knudsen and Clements 2013). All of them are herbivorous fishes and occur in shallow waters (0-10 m depth) in tropical and temperate rocky reefs (Topp 1970).

In the Mediterranean, two species of Kyphosidae have been reported: the beaked chub, Kyphosus sectatrix (Linnaeus, 1758), and the brassy chub, Kyphosus vaigiensis (Quoy et Gaimard, 1825). The former is more common in subtropical to temperate seas, but can also be encountered in more tropical areas (Knudsen and Clements 2013). It was listed in the Mediterranean fish fauna (Tortonese $1975,1986)$ based on old records (1846-1903) of a few individuals at Trieste, Palermo, and Genoa in Italy (Orsi Relini et al. 2011). Since then, it has been reported several times in the western and central Mediterranean, often under invalid names such as Kyphosus saltatrix (Linnaeus, 1758) (see Kiparissis et al. 2012; Lelong 2012; Elbaraasi et al. 2013) or Kyphosus sectator (Linnaeus, 1758) (see Hemida et al. 2004; Francour and Mouine 2008). Initially thought to be restricted to the Indo-Pacific, $K$. vaigiensis is a circumtropical species distributed along the Indian, Atlantic, and Pacific oceans, the Red Sea, and the Mediterranean (Knudsen and Clements 2013, 2016; Bañón et al. 2017; Evans et al. 2020). Not native to the Mediterranean, it was first reported three times under the species name Kyphosus incisor (Cuvier, 1831): twice in the vicinity of Almunécar (Granada, Spain) in the western Mediterranean Sea in June 1998 (Azzurro et al. 2013) and May 2013 (Peña-Rivas and Azzurro in Bilecenoglu et al. 2013) and along the Ligurian coast (Camogli, Italy) in July 2009 (Orsi Relini et al. 2011). Ligas et al. (2011) 
had confused it with an individual of Kyphosus saltatrix (see Knudsen and Clements 2013; Mannino et al. 2015) found in August 2009 not far from the port of Livorno in Italy. Additional occurrences were reported thereafter in Sicily (Mannino et al. 2015), Malta (Vella et al. 2016), Israel (Goren et al. 2016), Cyprus (Michailidis and Rousou in Gerovasileiou et al. 2017), and Turkey (Kiyağa et al. 2019). With the exception of Orsi Relini et al. (2011) who found 2 individuals of this species (only one of which was measured), all the other authors report only one specimen.

Kyphosus vaigiensis is inshore species found over hard bottoms. It can also occur offshore under floating objects or following ships (Nelson 1994). It feeds mainly on algae, including sargassum (Carpenter 2002). Silvano and Güth (2006) highlight the omnivory of this species in a Brazilian subtropical reef. Some data on the biology of its reproduction on the Colombian coasts are given by Rueda et al. (2015), but its biology and ecology are in general poorly known (Silvano and Güth 2006).

The present note describes a new record of $K$. vaigiensis in the Mediterranean. This species is reported for the first time on the coasts of North Africa.

\section{Methods}

On 18 December 2013, one individual of $K$. vaigiensis was recorded from the Gulf of Annaba (Fig. 1). Caught using a trammel net, it was found at a fishmonger among a batch of salemas, Sarpa salpa (Linnaeus, 1758). It was photographed, weighed, and identified based on both meristic and morphometric characters. These were taken following standard procedures used in other descriptions of sea chubs (Carpenter 2002; Sakai and Nakabo 2004; Orsi-Relini et al. 2011; Azzurro et al. 2013). The specimen was fixed in formalin and deposited in the fish collection of the Marine Bioresources Laboratory at the Annaba University, Algeria. Since this report in 2013, a survey has been conducted with fishermen in the region to find out if other individuals of $K$. vaigiensis have been seen. This survey was carried out based on photographs.

\section{Results}

The meristic and morphometric data of the fished specimen (Fig. 2) are listed in Table 1. They agree with the different descriptions of $K$. vaigiensis given by other authors (Sgano 1981; Carpenter and Niem 2001; Carpenter 2002; Orsi Relini et al. 2011; Azzurro et al. 2013; Sakai and Nakabo 2014, 2016). Morphologically, its body is oval shaped and moderately deep. The head is short with a small and horizontal mouth whose maxilla is slipping under edge of preorbital bone. Head profile in front of eye is gently convex (instead of a bump in K. sectatrix). Each jaw is provided with a regular row of close-set incisor-like, round-tipped teeth. Their bases set horizontally, resembling a radially striated bony plate inside mouth. Scales are ctenoid, small and rough to touch, covering most of the head. Color is dorsally grey to silvery on the belly. Series of longitudinal yellow-golden stripes across the body. On head, there are two brassy horizontal bands separated by a silver stripe under the eye. Fins and opercular membrane are dark.

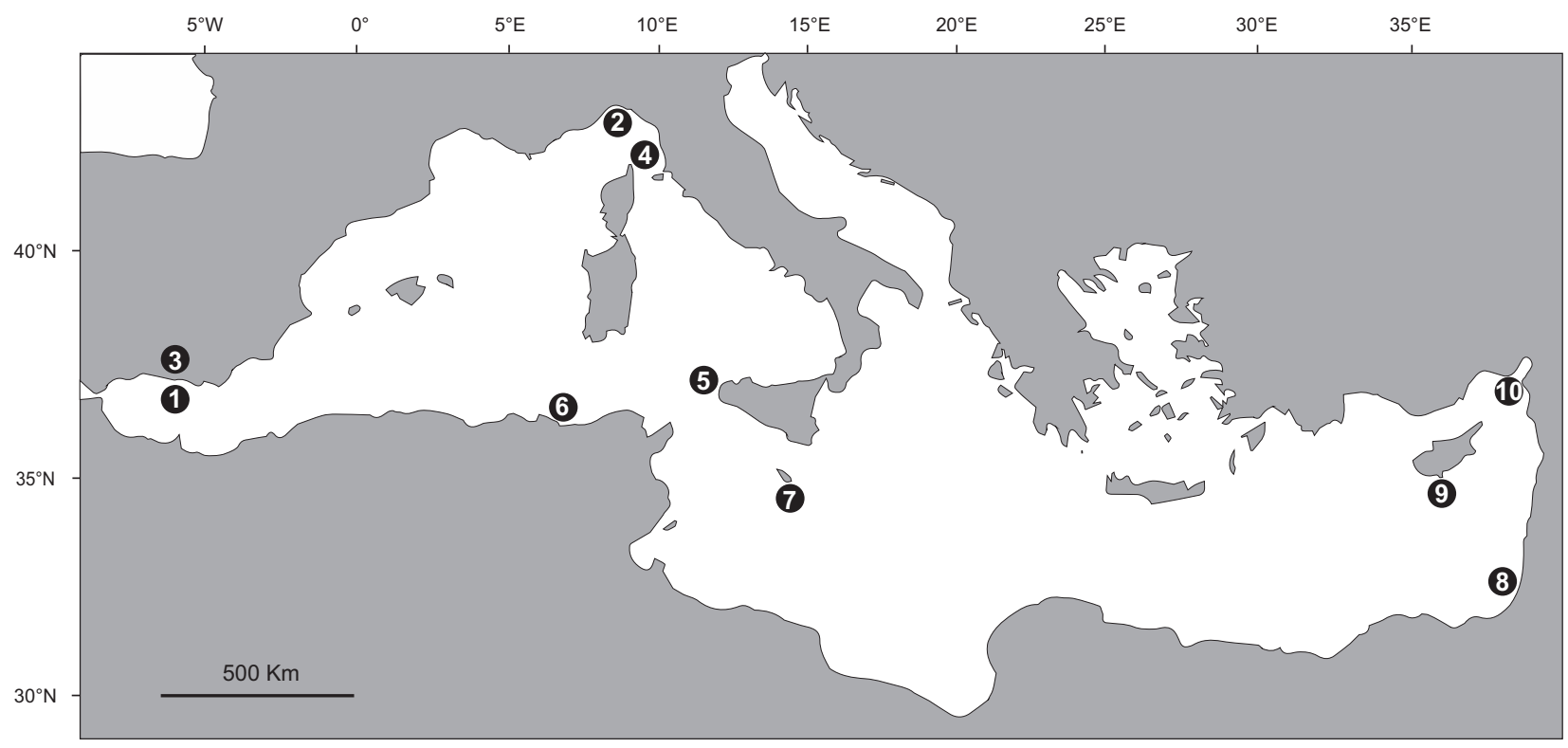

Figure 1. Map pointing out the capture locality of Kyphosus vaigiensis on Algerian coasts and chronology of the other records in the Mediterranean: 1 = Azzurro et al. (2013) (31 cm TL, $0.45 \mathrm{~kg} \mathrm{TW}), 2=$ Orsi Relini et al. (2011) (48 cm TL, $1.80 \mathrm{~kg} \mathrm{TW}), 3=$ Bilecenoglu et al. (2013) (46 cm TL, $1.64 \mathrm{~kg}$ TW), $4=$ Ligas et al. (2011) (49.5 cm TL, $1.65 \mathrm{~kg}$ TW), $5=$ Mannino et al. (2015) (47.5 cm TL), 6 = presently reported finding ( $45.1 \mathrm{~cm} \mathrm{TL}, 1.27 \mathrm{~kg} \mathrm{TW}), 7=$ Vella et al. (2016) $(15.7 \mathrm{~cm} \mathrm{TL}, 0.49 \mathrm{~g}$ EW), $8=\mathrm{Goren}$ et al. (2016) (42.0 cm SL), 9 = Michailidis and Rousou in Gerovasileiou et al. (2017) (27.2 cm TL, $403 \mathrm{~g} \mathrm{TW}), 10=$ Kiyağa et al. (2019) (53.1 cm TL, $2.27 \mathrm{~kg} \mathrm{TW})$. 


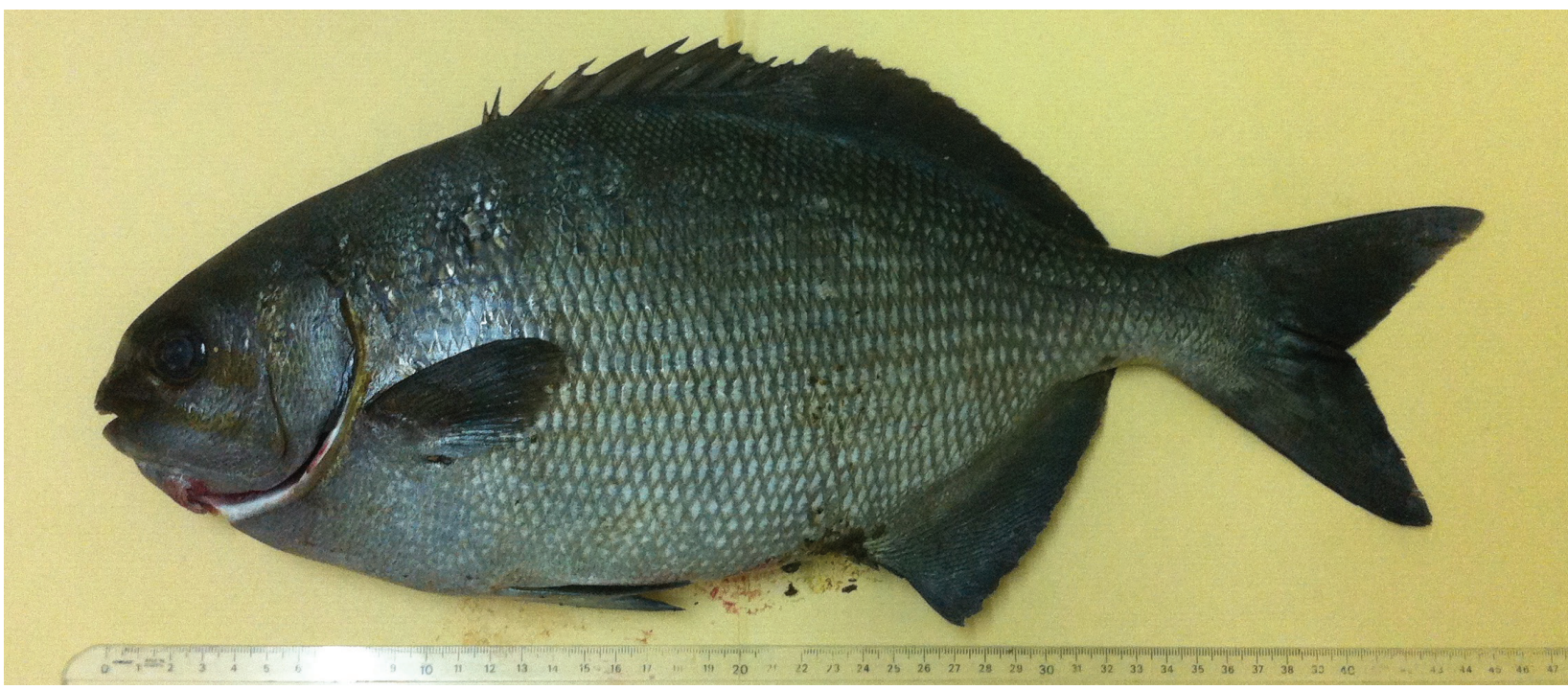

Figure 2. Specimen of Kyphosus vaigiensis (41.5 cm TL, $1.27 \mathrm{~kg} \mathrm{TW}$ ) caught in the Gulf of Annaba, Algeria in December 2013.

Table 1. Morphometric and meristic characters of Kyphosus vaigiensis captured off Annaba coast (eastern Algeria) in December 2013.

\begin{tabular}{|c|c|}
\hline \multicolumn{2}{|c|}{ Morphometric characters [cm] } \\
\hline Total length & 41.5 \\
\hline Fork length & 38.0 \\
\hline Standard length & 31.0 \\
\hline Head length & 9.2 \\
\hline Head depth at end of operculum & 13.0 \\
\hline Head depth at end of orbit & 9.5 \\
\hline Head width at operculum & 6.2 \\
\hline Eye diameter & 2.0 \\
\hline Pre-orbital length & 3.0 \\
\hline Post-orbital length & 4.3 \\
\hline Body width at dorsal origin & 6.1 \\
\hline Body width at anal origin & 5.0 \\
\hline Body height & 15.5 \\
\hline Pre-dorsal length & 11.2 \\
\hline Pre-anal length & 21.0 \\
\hline Caudal peduncle depth & 3.5 \\
\hline Caudal peduncle length & 4.0 \\
\hline Dorsal fin base length & 16 \\
\hline Pectoral fin length & 6.5 \\
\hline Pectoral fin base length & 2.0 \\
\hline Pelvic fin length & 6.0 \\
\hline Pelvic fin base length & 2.0 \\
\hline Anal fin base length & 9.6 \\
\hline Caudal fin height (vertically extended) & 16.0 \\
\hline Caudal fin length & 9.0 \\
\hline Internasal space & 2.4 \\
\hline Inter-orbital distance & 4.2 \\
\hline Upper jaw length & 3.0 \\
\hline Lower jaw length & 1.8 \\
\hline $6^{\text {th }}$ dorsal fin spine (longest) & 3.7 \\
\hline $4^{\text {th }}$ dorsal fin ray (longest) & 2.9 \\
\hline Total weight $[\mathrm{g}]$ & 1270 \\
\hline \multicolumn{2}{|l|}{ Meristic characters } \\
\hline Dorsal fin spines and soft rays & $\mathrm{XI}+13$ \\
\hline Anal fin spines and soft rays & $\mathrm{III}+12$ \\
\hline Pectoral fin rays & 17 \\
\hline Pelvic fin spines and soft rays & $\mathrm{I}+5$ \\
\hline Caudal fin rays & 18 \\
\hline Pored scales in lateral line & 60 \\
\hline Scales rows above lateral line & 11 \\
\hline Scales rows below lateral line & 17 \\
\hline Gill rackers on first arch (upper limb + lower limb) & $10+19$ \\
\hline Incisor-like teeth on upper jaws & 31 \\
\hline Incisor-like teeth on lower jaws & 32 \\
\hline
\end{tabular}

\section{Discussion}

The morphology of the caught specimen, as well as its chromatic, meristic, and metric characteristics, confirm that it represents $K$. vaigiensis, as described in the literature (Tortonese 1975, 1986; Sgano 1981; Carpenter 2002; Knudsen and Clements 2013; Carpenter and De Angelis 2016; Sakai and Nakabo 2016) and by the authors of other records of this species in the Mediterranean (Ligas et al. 2011; Orsi Relini et al. 2011; Azzurro et al. 2013; Mannino et al. 2015; Goren et al. 2016; Vella et al. 2016; Michailidis and Rousou in Gerovasileiou et al. 2017; Kiyağa et al. 2019). In particular, Azzurro et al. (2013) insist on the morphological characters which differentiate $K$. vaigiensis from its congener $K$. sectatrix, two very similar species who cohabit in the Mediterranean: anal fin with 12 or 13 soft rays (11, rarely 10 or 12 in $K$. sectatrix), 19 to 22 gill rakers on the lower limb of first gill arch (16 to 19 , rarely 19 in $K$. sectatrix) and the gently convex head profile in front of eye (a distinct bump in K. sectatrix).

Among the fifteen fishermen we surveyed, two confirmed that they had encountered this fish once. A single individual in the first case (date not specified) and two in the second (in 2019), both of size not exceeding $30 \mathrm{~cm}$. However, given the morphologic similarity between the two species $K$. vaigiensis and $K$. sectatrix, it was not possible to confirm which of the two species it was.

This additional record of $K$. vaigiensis from the Mediterranean confirms its spread along the North-African coast. None of the ichthyological inventories carried out on the Algerian coasts had mentioned it (Dieuzeide et al. 1954; Djabali et al. 1993; Derbal and Kara 2001). This species is the tenth non-indigenous marine fish recorded in Algeria, but the first of circumtropical origin. All the other alien species that arrived are Lessepsian migrants of Indian or Indo-Pacific origin (Kara and Bourehail 2020).

The introduction of $K$. vaigiensis in the Mediterranean could be attributed to the natural expansion of its range 
(Zenetos et al. 2012). Its adults can travel long distances (Azzurro et al. 2013) and its juveniles are pelagic and found associated with floating objects (Knudsen and Clements 2016). Thereby, it would have arrived actively or passively through the Suez Canal or the Strait of Gibraltar. However, the chronology of its occurrences which shows a clear spatial progression from west to east and a recent entry (after 2015) into the eastern Mediterranean supports the hypothesis of its Atlantic origin. Otherwise, Annaba being a port city, receiving hundreds of ships per year from all regions of the world (around 10000 visit Algerian ports each year; Cheniti et al. 2018), its coasts are exposed to the introduction of exotic species. Thus, the recorded $K$. vaigiensis individual would have arrived by ships' ballast water from one of its natural geographic ranges. Indeed, sea chubs are often observed around ships in subtropical waters waiting for the dumping of garbage (Orsi Relini et al. 2011) and are commonly referred to as "rudderfish" (Evans et al. 2020). This behavior exposes them to being "embarked" on board the boats. Thus, their presence in the Mediterranean can also be considered as humanmediated as proposed by Lo Brutto (2017).

\section{References}

Azzurro A, Pena-Rivas L, Lloris D, Bariche M (2013) First documented occurrence of Kyphosus incisor in the Mediterranean Sea. Marine Biodiversity Records 6: e98. https://doi.org/10.1017/ S1755267213000717

Bañón R, Barros-García D, de Carlos A (2017) Integrative taxonomy supports the presence of two species of Kyphosus (Perciformes: Kyphosidae) in Atlantic European waters. Scientia Marina 81(4): 467-475. https://doi.org/10.3989/scimar.04601.08A

Bilecenoglu M, Alfaya J, Azzurro E, Baldacconi R, Boyaci Y, Circosta V, Compagno L, Coppola F, Deidun A, Durgham H, Durucan F, Ergüden D, Fernández-Álvarez F, Gianguzza P, Giglio G, Gökoğlu M, Gürlek M, Ikhtiyar S, Kabasakal H, Karachle P, Katsanevakis S, Koutsogiannopoulos D, Lanfranco E, Micarelli P, Özvarol Y, Pena-Rivas L, Poursanidis D, Saliba J, Sperone E, Tibullo D, Tiralongo F, Tripepi S, Turan C, Vella P, Yokeş M, Zava B (2013) New Mediterranean Marine biodiversity records (December, 2013). Mediterranean Marine Science 14(2): 463-480. https://doi. org/10.12681/mms.676

Carpenter KE (2002) Kyphosidae: sea chubs. In: Carpenter KE (Ed.) FAO species identification guide for fishery purposes. The living marine resources of the western central Atlantic. Vol. 3. Bony fishes. Part 2. (Opistognathidae to Molidae), sea turtles and marine mammals. FAO, Rome, 1684-1687.

Carpenter KE, De Angelis N [Eds] (2016) The living marine resources of the Eastern Central Atlantic. Vol. 2: Bivalves, gastropods, hagfishes, sharks, batoid fishes, and chimaeras. FAO Species Identification Guide for Fishery Purposes. FAO, Rome, 665-1509.

Carpenter KE, Niem VH [Eds] (2001) FAO species identification guide for fishery purposes. The living marine resources of the Western Central Pacific. Vol. 5. Bony fishes part 3 (Menidae to Pomacentridae). FAO, Rome, 2791-3380.
Until now, records of $K$. vaigiensis in Mediterranean are limited to one or two isolated individuals. As $K$. sectatrix (see Francour and Mouine 2008), it can be considered a neocolonizer species sensu Quignard and Tomasini (2000). However, in the current context of seawater warming, the ability of $K$. vaigiensis to travel over large distances and its thermophilic character could in the future facilitate its establishment in the Mediterranean. In this situation, its coexistence with the indigenous sparid Sarpa salpa, the only herbivorous fish species in the Mediterranean, would reproduce the interaction scenario between Sarpa salpa, Siganus luridus (Rüppell, 1829), and Siganus rivulatus Forsskål et Niebuhr, 1775 which happened in the eastern Mediterranean.

\section{Acknowledgments}

The authors thank the Algerian Ministry of Higher Education and Scientific Research (General directorate for scientific research and technology development, GDRSDT) which financially supported this study, within the framework of the National Funds of Research (NFR).

Cheniti R, Rochon A, Frihi H (2018) Ship traffic and the introduction of diatoms and dinoflagellates via ballast water in the port of Annaba, Algeria. Journal of Sea Research 133: 154-165. https://doi. org/10.1016/j.seares.2017.07.008

Derbal F, Kara MH (2001) Inventaire des poissons des côtes de l'Est algérien. Rapport Commission Internationale de la Mer Méditerranée 36: 258 .

Dieuzeide R, Novella M, Roland J (1954) Catalogue des poissons des côtes algériennes. II. Ostéoptérygiens. Bulletin de la Station d'Aquaculture et de Pêche de Castiglione, n. s., Alger, 258 pp.

Djabali F, Brahmi B, Mammasse M (1993) Poissons des côtes algériennes. Pelagos Numéro spécial, 215 pp.

Elbaraasi H, Bogarara O, Elsilini O, Bojwari J (2013) First record of the Bermuda sea chub, Kyphosus saltatrix (Actinopterygii: Perciformes: Kyphosidae), in the coastal waters of Libya. Acta Ichthyologica et Piscatoria 43(3): 251-253. https://doi.org/10.3750/ AIP2013.43.3.09

Evans J, Arndt E, Schembri PJ (2020) Atlantic fishes in the Mediterranean: Using biological traits to assess the origin of newcomer fishes. Marine Ecology Progress Series 643: 133-143. https://doi. org/10.3354/meps 13353

Francour P, Mouine N (2008) First record of Kyphosus sectator (Kyphosidae) along the French Mediterranean coast. Cybium 32(3): 275-276.

Gerovasileiou V, Akel EHKh, Akyol O, Alongi G, Azevedo F, Babali N, Bakiu R, Bariche M, Bennoui A, Castriota L, Chintiroglou CC, Crocetta F, Deidun A, Galinou-Mitsoudi S, Giovos I, Gökoğlu M, Golemaj A, Hadjioannou L, Hartingerova J, Insacco G, Katsanevakis S, Kleitou P, Korun J, Lipej L, Malegue M, Michailidis N (2017) New Mediterranean Biodiversity Records. Mediterranean Marine Science 18(2): 355-384. https://doi.org/10.12681/mms.13771 
Goren M, Galil B, Roy G, Nir S (2016) First record of the brassy chub Kyphosus vaigiensis (Quoy et Gaimard, 1825) in the Eastern Mediterranean (Osteichthyes: Perciformes: Kyphosidae). Zoology in the Middle East 62(4): 319-322. https://doi.org/10.1080/09397140.201 6.1250710

Hemida F, Kanoun N, Golani D, Ben Souissi J, Guelorget O, Capapé C (2004) Records of the Bermuda sea chub, Kyphosus sectator (Linnaeus, 1758) (Osteichthyes: Kyphosidae) from the coastal waters of Algeria (southern Mediterranean). Annales. Series Historia Naturalis 14(1): 49-52.

Humann P (1994) Reef fish identification: Florida, Caribbean, Bahamas. $2^{\text {nd }}$ edn. New World Publications, Jacksonville, 396 pp.

Kara MH, Bourehail N (2020) First record of the Indo-Pacific yellowtail barracuda Sphyraena flavicauda (Actinopterygii: Perciformes: Sphyraenidae) in the Western Mediterranean. Acta Ichthyologica et Piscatoria 50(3): 363-366. https://doi.org/10.3750/AIEP/02987

Kiparissis S, Loukovitis D, Batargias C (2012) First record of the Bermuda sea chub Kyphosus saltatrix (Pisces: Kyphosidae) in Greek waters. Marine Biodiversity Records 5(e11): e11. https://doi. org/10.1017/S1755267211001199

Kiyağa VB, Mavruk S, Özyurt CE, Akamca E, Coşkun Ç (2019) Range extension of Kyphosus vaigiensis (Quoy et Gaimard, 1825) in the northeastern Mediterranean, İskenderun Bay, Turkey. Turkish Journal of Zoology 43(6): 644-649. https://doi.org/10.3906/zoo-1901-1

Knudsen SW, Clements KD (2013) Revision of the fish family Kyphosidae (Teleostei: Perciformes). Zootaxa 3751(1): 1-101. https://doi. org/10.11646/zootaxa.3751.1.1

Knudsen SW, Clements KD (2016) World-wide species distributions in the family Kyphosidae (Teleostei: Perciformes). Molecular Phylogenetics and Evolution 101: 252-266. https://doi.org/10.1016/j. ympev.2016.04.037

Knudsen SW, Choat JH, Clements KD (2019) The herbivorous fish family Kyphosidae (Teleostei: Perciformes) represents a recent radiation from higher latitudes. Journal of Biogeography 46: 2067-2080. https://doi.org/10.1111/jbi.13634

Lelong P (2012) A new record of Bermuda sea chub, Kyphosus saltatrix (Linnaeus, 1758), (Osteichthyes, Kyphosidae) from Galite Islands (Tunisia, southern Mediterranean). Marine Life (Marseille) 18(1): 3-7.

Ligas A, Sartor P, Sbrana M, de Ranieri S (2011) A new record of Kyphosus saltatrix (Pisces: Kyphosidae) along the Italian coasts (north-western Mediterranean). Marine Biodiversity Records 4: e6. https://doi.org/10.1017/S1755267210001211

Lo Brutto S (2017) The case of a rudderfish highlights the role of natural history museums as sentinels of bio-invasions. Zootaxa 4254(3): 382. https://doi.org/10.11646/zootaxa.4254.3.8

Mannino AM, Balistreri P, Iaciofano D, Galil BS, Lo Brutto S (2015) An additional record of Kyphosus vaigiensis (Quoy et Gaimard, 1825) (Osteichthyes, Kyphosidae) from Sicily clarifies the confused situation of the Mediterranean kyphosids. Zootaxa 3963(1): 45-54. https://doi.org/10.11646/zootaxa.3963.1.3

Nelson JS (1994) Fishes of the world. $3^{\text {rd }}$ edn. John Wiley and Sons, New York, 600 pp.

Orsi Relini L (2017) Notes on recent revisions of the taxonomy of Kyphosidae. Biologia Marina Mediterranea 24(1): 206-208.
Orsi Relini L, Costa MR, Relini M (2011) First record of the yellow sea chub Kyphosus incisor in the Mediterranean. Marine Biodiversity Records 4: 1-3. https://doi.org/10.1017/S1755267209991096

Quignard JP, Tomasini JA (2000) Mediterranean fish diversity. Biologia Marina Mediterranea 7: 1-66.

Rueda M, Bolivar VW, Bustos-Montes D, Osorio SP, Sanjuanelo A, Rodriguez A, Correa MC (2015) Parametros biologico-pesqueros del striped chub (Kyphosus incisor) relevantes para su manejo y conservacion en el parque nacional natural old providence McBean lagoon. Bolletin Investigacione Marine Coasts 44(1): 71-92. https:// doi.org/10.25268/bimc.invemar.2015.44.1.21

Sakai K, Nakabo T (1995) Taxonomic review of the Indo-Pacific kyphosid fish, Kyphosus vaigiensis (Quoy and Gaimard). Japanese Journal of Ichthyology 42(1): 61-70. https://doi.org/10.11369/JJI1950.42.61

Sakai K, Nakabo T (2004) Two new species of Kyphosus (Kyphosidae) and a taxonomic review of Kyphosus bigibbus Lacepède from the Indo-Pacific. Ichthyological Research 51(1): 20-32. https://doi. org/10.1007/s10228-003-0186-2

Sakai K, Nakabo T (2014) Taxonomic review of Kyphosus (Pisces: Kyphosidae) in the Atlantic and Eastern Pacific Oceans. Ichthyological Research 61(3): 265-292. https://doi.org/10.1007/s10228014-0395-x

Sakai K, Nakabo T (2016) Kyphosidae. In: Carpenter KE, De Angelis $\mathrm{N}$ (Eds) The living marine resources of the Eastern Central Atlantic. Vol. 4. FAO, Rome, 2680-2685.

Sgano T (1981) Kyphosidae. In: Fischer W (Ed.) FAO species identification sheet for fishery purposes. Eastern Central Atlantic (Fishing Areas 34, 47 in part). Vol. 2. FAO, Rome.

Silvano RAM, Güth AZ (2006) Diet and feeding behavior of Kyphosus spp. (Kyphosidae) in a Brazilian Suubtropical Reef. Brazilian Archives of Biology and Technology 49(4): 623-629. https://doi. org/10.1590/S1516-89132006000500012

Topp RW (1970) Behavior and color change of rudderfish, Kyphosus elegans, in Gulf of Panama. Copeia 4(4): 763-765. https://doi. org/10.2307/1442322

Tortonese E (1975) Fauna d'Italia. Osteichthyes (Pesci Ossei), Vol. 11. Calderini, Bologna, $636 \mathrm{pp}$.

Tortonese E (1986) Kyphosidae. In: Whitehead PJP, Bauchot ML, Hureau JC, Nielsen J, Tortonese E (Eds) Fishes of the northeastern Atlantic and the Mediterranean, Vol. 2. UNESCO, Paris, 912-913. https://doi.org/10.2307/1444931

Vella N, Vella A, Darmanin SA (2016) The first record of the lowfin chub Kyphosus vaigiensis (Quoy et Gaimard, 1825) from Malta. Journal of Black Sea/Mediterranean Environment 22(2): 175-181.

Zenetos A, Gofas S, Morri C, Rosso A, Violanti D, Garcia Raso JE, Cinar ME, Almogi-Labin A, Ates AS, Azzurro E, Ballesteros E, Bianchi CN, Bilecenoglu M, Gambi MC, Giangrande A, Gravili C, HyamsKaphzan O, Karachle PK, Katsanevakis S, Lipej L, Mastrototaro F, Mineur F, Pancucci-Papadopoulou MA, Ramos Espla A, Salas C, San Martin G, Sfriso A, Streftaris N, Verlaque M (2012) Alien species in the Mediterranean Sea by 2012. A contribution to the application of European Union's Marine Strategy Framework Directive (MSFD). Part 2. Introduction trends and pathways. Mediterranean Marine Science 13(2): 328-352. https://doi.org/10.12681/mms.327 